\title{
Teacher Candidate Immersion into Bilingual/ Dual Language Classrooms in Largest Urban District in Texas
}

\author{
Bobbette M. Morgan ", Criselda Garcia, John Jauregui \\ Department of Teaching and Learning, College of Education and P-16 Integration, University of Texas Rio Grande Valley, \\ United States
}

Copyright $(2019$ by authors, all rights reserved. Authors agree that this article remains permanently open access under the terms of the Creative Commons Attribution License 4.0 International License

\begin{abstract}
Prevailing teacher education reform initiatives call for preservice preparation to be "clinically rich" shifting the primary locus, and therefore location, of learning from within university walls to schools (National Council for Accreditation of Teacher Education, 2010; New York State Department of Education, 2011; U. S. Department of Education, 2009, 2011). In an effort of the largest school district in Texas to recruit our bilingual preservice teachers and for us to expose our students from the Rio Grande Valley to a highly populated urban setting, our students are invited to spend one week with host families and shadow an experienced teacher in dual language classrooms. As they are immersed in urban classroom's activities and community events, bilingual teacher candidates are exposed to a full array of a teacher's role and responsibilities. This experience is in addition to their field-based assignments as part of their educator preparation program and student/ clinical teaching. Although teacher candidates pend completion of clinical teaching, graduation and state certification, they receive letters of intent from district officials at the end of their week-long visit Journals and essays kept by the students were analyzed through three qualitative processes by the researchers: NVivo, Excel, and color-coding of themes and sub-themes. Qualitative findings suggested central phenomena was identified relating to bilingual/ dual language practices in the classrooms along with relating common subthemes of diversity, instructional strategies, routines, differences from the Valley, feelings/ emotions, bonding, and classroom management.
\end{abstract}

Keywords Clinical Practice, Teacher Candidate, Preservice Teacher, Qualitative Study

\section{Introduction}

The lens for examining the process of the preservice teacher learning and knowledge-construction can be defined by tenants of cognitive constructivism and social constructivism theories. Cognitive constructivism focuses on learners' roles in knowledge construction and their learning processes (Piaget, 2001). Vygotsky believed people could learn with much scaffolding from others. While cognitive constructivism relates mostly to an individual's cognitive development, social constructivism centers on how we learn with and through others (Kozulin, 1986, Vygotsky, 1978). Piaget and Vygotsky perceived interactions with more-able peers and instructors as a result of cognitive development; both perceived learners to be agents in their learning (Sawyer \& Obeid, 2017).

As teacher candidates' journey through their preparation programs, they engage in multiple opportunities to close the gap between theory and practice and construct understandings through their field work and experiences in K-12 schools. Field-based assignments involved reflection of these experiences in the form of journals and essays. Preservice teacher reflection serves as a valuable tool to capture new learning from intentional clinically-rich experiences. Teacher reflection remains a well-documented critical component of preparing teachers for the complexity of the profession. Although there are multiple significant contributions to the framework of reflection, the literature review shows a variety of definitions for reflection. Major contributors were Dewey's (1933) and Schon's (1987) theories on developing this framework on reflection with Dewey emphasizing a mindset of open-mindedness and focus on the cognitive aspects (Ulusoy, 2016), while others looked at the decision-making outcomes in forms of actions that resulted from reflection. Despite the different definitions, preparing preservice teachers to engage in reflection activities reaps a multitude of benefits. For this study, Rogers (2001) purpose of reflection seems the most suitable as he explains that teaching may be improved through the intentional practice of reflection. 
With use of reflection as a tool for processing the experiences, basic theoretical constructs serve as the basis for the continuous connecting of theory to practice. Through a structured field experience, bilingual preservice teachers were offered opportunities to evaluate their learning experiences through examination of important aspects of four learning domains discussed by Dettmer (2006) as cognitive, affective, social and psychomotor. Using these domains, preservice teachers looked critically at areas such as instructional practices and strategies, interactions and learning environments. Significantly, affirming this line of construct in building understandings are recent research in neuroscience that have begun to highlight the role of subjective, emotional, social experiences in meaningful learning that can be transferred to real world situations (Immordino-Yang, 2016). Despite a long tradition of attempting to divorce rational aspects of meaning making from our emotional sense-making (Damasio, 2003) the process of learning is intricately bound up with our feelings. Insights from affective neuroscience are uncovering that 'it is literally neurobiologically impossible to build memories, engage complex thoughts, or make meaningful decisions without emotion' (Immordino-Yang, 2016). Urban schools have greater needs to have teachers who express a caring attitude. The literature shows these children may experience a greater need to develop close relationships with teachers (Brown, 2004) who show warmth and affection to their students and see their relationship with students as a priority.

Another theoretical construct to serve as a basis for connecting theory to practice in relation to cultural diversity and social justice was defined by the work of Nieto (2005). Nieto (2005) has identified five attitudinal qualities that she considers essential for teachers to be effective promoters of cultural diversity and social justice. They are (a) a sense of mission to serve ethnically diverse children to the best of their abilities; (b) solidarity with, empathy for, and value of students' lives, experiences, cultures, and human dignity; (c) courage to question mainstream school knowledge and conventional ways of doing things, and beliefs and assumptions about diverse students, families, cultures, and communities; (d) willingness to improvise, to push the envelope, to go beyond established templates and frameworks, and to embrace uncertainty and flexibility; and (e) a passion for equality and social justice. The cultivation of these attitudes could constitute the core of teacher education programs devoted to developing beliefs that are ideological anchors for incorporating cultural diversity into teaching behaviors.

To examine the practice in bilingual and dual language classrooms, Cummins (2008) descriptions of bilingual education as "the use of two (or more) languages of instruction" were utilized. Garcia, Skutnabb-Kangas, and Torres-Guzman (2006) elaborate that these multilingual schools "exert educational effort that takes into account and builds further on the diversity of languages and literacy practices that children and youth bring to school" (p. 14). This means going beyond acceptance or tolerance of children's languages, to "cultivation" of languages through their use for teaching and learning. Cummins referred to research (August \& Shanahan, 2006; Genesee, Lindholm-Leary, Saunders, \& Christian, 2006) that demonstrates that considerable confidence can be placed in the positive outcomes of bilingual education. Consistent with theories of effective implementation of bilingual education, these practices rely heavily on the teacher supporting both languages through authentic interactions in positive learning environments that integrate a biliteracy approach to use language and literacy to communicate (Perez \& Torres-Guzman, 2002).

Research in the area of learning environments and classroom management served to frame the observations and experiences in K-12 classrooms. As Jacob Kounin's (1970) work on managing the environment and pace effectively demonstrates, by planning highly engaged activities very well, teachers avoid some common pitfall falls. Specifically, research has shown us that teachers' actions in their classrooms have twice the impact on student achievement as do school policies regarding curriculum, assessment, staff collegiality, and community involvement (Marzano, 2003a). We also know that one of the classroom teacher's most important jobs is managing the classroom effectively. Wang, Haertel, and Walberg (1993) amply demonstrate the importance of effective classroom management. These researchers analyzed 86 chapters from annual research reviews, 44 handbook chapters, 20 government and commissioned reports, and 11 journal articles to produce a list of 228 variables affecting student achievement. They combined the results of these analyses with the findings from 134 separate meta-analyses. Of all the variables, classroom management had the largest effect on student achievement. This makes intuitive sense - students cannot learn in a chaotic, poorly managed classroom.

In a meta-analysis of more than 100 studies (Marzano, 2003b), researchers found that the quality of teacher-student relationships is the keystone for all other aspects of classroom management. In fact, the meta-analysis indicates that on average, teachers who had high quality relationships with their students had 31 percent fewer discipline problems, rule violations, and related problems over a year's time than did teachers who did not have high-quality relationships with their students.

The week-long placement mutually benefited both the largest school district in Texas to recruit our bilingual preservice teachers and provided us an opportunity to expose our preservice teachers to a highly populated urban setting. During the special placement, our students spend one week with host families and shadowed an experienced teacher in a dual language classroom. Along with this 
experience came exposure to a full array of a teacher's role and responsibilities and multiple opportunities to connect theory to practice through reflection. They were immersed in the urban classroom's activities and community events. After the week-long internship, students received letters of intent from district officials although they must complete clinical practice in their Rio Grande Valley communities and become certified to be hired. Journals and essays were analyzed through three qualitative processes: NVivo, Excel, and color-coding. Common themes identified include diversity, instructional strategies, routines, differences from the Valley, feelings/emotions, bonding, and classroom management.

\section{Purpose}

The qualitative study is based on written journals kept by nine preservice teachers who completed one-week internships in the largest school district in Texas from May 21-26, 2018. Student journals summarized what they experienced. Based on the journal entries, the nine students each prepared a three-page essay summarizing their week-long school visits. Professors wanted our preservice teachers to observe a "positive trend favoring inquiry-based instructional practices, particularly instruction that emphasizes students' active thinking and drawing conclusions from data. Teaching strategies that actively engage students in the learning process through scientific investigations are more likely to increase conceptual understanding than are strategies that rely on more passive techniques (p. 474)".

\section{Research Questions}

1. What do preservice teachers learn and report after spending a week in a highly populated, diverse urban school district?

2. What research-based instructional strategies were observed?

3. What are the significant commonalities of the overall experience?

\section{Perspectives}

\subsection{Methods}

This study used data from nine preservice teachers at a designated Hispanic Serving Institution (HSI) from 2018 in a city with 170,000 residents. During data gathering, approximately 29,000 students attended the university; over $96 \%$ were Latinos and over $87 \%$ were first-generation college students. This Texas public university, offering bachelor's, master's, and doctoral degrees, situates itself along the U.S./ Mexico border. According to the U.S. Census Bureau (2010), about 33\% of residents in this city lived in poverty, with a per capita income of $\$ 14,000$; approximately $87 \%$ are Spanish-speaking and $93 \%$ are Latino/a. Students completed their one-week internships in the largest school district in Texas. About 11 hours north of the home institution, students stayed with host families and were exposed to a variety of activities, i.e., attending a professional baseball game, shopping at the Galleria, riding the short-rail transit system, seeing a professional production of the Lion King, and visiting art museums.

An Institutional Review Board proposal was developed, submitted for review, and approved for this study. Researchers decided to approach the qualitative review of data through grounded theory. In grounded theory studies, data collection is field-based, flexible and organic with high likelihood of changes occurring throughout the process (Leedy \& Ormrod, 2016). As with any grounded theory study, the theories emerge from the data collected in the field. With a strong emphasis on the process related to the teacher candidate's experiences in a week-long placement in schools in the largest school district in Texas, collecting field notes in the form of journals and essays supported the study's aim of capturing significant commonalities of the overall experience.

\subsection{Data Sources}

Preservice teachers kept journals for the week they spent with an experienced teacher in the teacher's classroom in the largest school district in Texas. Most students were assigned to dual language classrooms where Spanish was spoken for some subjects and English for others. The percentage of Spanish versus English varied by grade level. Three-page essays were required, based upon the preservice teachers' journal entries. Other data sources included written directions given to students about topics they might include in the journal, i.e., instructional strategies, diversity, similarities and differences from the Valley.

Prior to leaving the Rio Grande Valley two researchers met with the preservice teachers to provide expectations about data collection. They received written guidelines to consider as they documented their days in class with mentor teachers. They were asked to think about how what they were seeing and experiencing was similar to the Valley and what was different. They were also asked to identify research-based instructional strategies they recognized. Each preservice teacher received a notebook to keep their daily entries organized. Notebooks and three-page essays were turned in two weeks after returning from their visit.

\subsection{Data Analysis}

Qualitative researchers examine data using various 
approaches in this process. Through a sociological lens, the most commonly used data analysis technique is to using thematic analysis, which is the process that requires coding then separating or "chunking" data by codes for more analysis and description (Glesne, 2006). A critical factor in this process is the researcher who organizes data to make sense of what is learned through a deep interpretation. Each researcher brings a set of experiences, tentative explanations, pose hypotheses and theories stemming from these experiences. In this study, a unique glimpse into three various methods of analyzing data for each of the researchers was another way of triangulating data and confirming the story to be told. To answer the research questions, through multiple techniques, the researchers explored data through a transformative process described by Wolcott (1994) as description, analysis, and interpretation in moving from organization to meaning (as cited in Glesne, 2006).

Initially, description means staying close to the original data in the form of journal notes and essays. Next through multiple inspection of the data, analysis takes shape by identifying key themes in the study and relationships. Finally, there is an interpretation of the data, meaning there is deliberate analysis by using theory to provide structure, and making the necessary connections to tell the whole story. Unique in this study were the three distinct approaches each researcher undertook to transform the data and multiple triangulation sessions to confirm the findings. Significantly, although the process of analysis varied, each researcher transformed the data through various phases to arrive at common themes.

The data analysis process varied among the three researchers. Appropriate to a grounded theory study, through the thorough analysis of data, themes are revealed which relate directly to theoretical constructs rooted in constructivism and social constructivism. By triangulating data ascertained through multiple methods of analysis, each process was described and overlapping themes emerged from the various processes. Discussions amongst the researchers describing the process and findings were recursive and essential to the final analysis.

One researcher used a computer-assisted software program NVivo 12 QSR to assist with the qualitative data analysis process. As noted by Leech and Onwuegbuzie (2011), these types of qualitative data analysis tools have the potential to take data analysis further (p. 71). The researcher used NVivo 12 to conduct a constant comparison analysis. This type of analysis utilized with NVivo is one of the most popular amongst qualitative researchers because of the flexibility with sources, types and size of text to be analyzed (Leech \& Onwuegbuzie, 2011). The software analysis program includes codes in the form of what are known as "nodes", which represent themes, concepts, ideas, opinions or experiences. These are broad categories that help the deductive process of beginning with a general assignment of placing meaning on different parts of the documents collected. Each node has "sub-nodes", which are more specific ideas related to broader themes. Using the question prompts given to the participants, four general themes were developed as nodes: instructional strategies, comparisons to schools in Rio Grande Valley, feelings/emotions and other emerging themes. These nodes were used to code the documents. In NVIVO text is highlighted and code selection is used to designate this theme. As the documents were analyzed, any new themes that reoccurred were coded at the emerging theme node.

In this deductive process, upon initial analysis, there were sub-nodes resulting from the broad theme of instructional strategies. These evolved into commentaries relating specifically to bilingual/dual language instruction, classroom management and other learning strategies. Documents were coded at these sub-node levels. To determine the frequency in which these themes emerged, queries were run resulting in reports noting the number of references relating to each theme. In this process, the highest number of references were attributed to feelings/emotions captured in the documents with 26 references; the second highest were learning strategies with 25 references and bilingual/dual language instructional strategies with 24 references. Some overlapping themes that emerged were between bilingual/dual language instruction and comparison to schools in the Rio Grande Valley with 18 references. Based on this analysis, the most significant finding was that a very high number of references and commentary by all participants were identified.

A second researcher took the approach of examining teacher candidates' journal entries during the one-week placement via an inductive approach. Examples and details of observed occurrences and statements were coded and then grouped into broader themes. In this analysis, the researcher placed all coded items and themes in an Excel spreadsheet and filtered reoccurring themes. During this time, there was also an analysis to determine sub-themes to highlight emerging specificity. The filtering phase of the themes revealed teacher candidates' references to instruction and learning activities at 51 with the second highest referenced theme centering on some aspect of the campus's functions at 35 . A closer review of the latter revealed teacher candidates observing more of the campus's expectation, planning and routines and procedures, 17 references. These observations most likely are responses to the guiding prompt of writing down what you noticed. Lastly, references to feelings/emotions, reflective thoughts, and classroom management were noted as themes at 30,28, and 14, respectively. This initial analysis approach yielded similar results to the prior researcher, with the exception of identifying the overlapping themes of bilingual/dual language instruction and specific comparisons to schools in the Rio Grande Valley. 
The third researcher read and reread the journals and essays multiple times and then color-coded the documents based on emerging themes. For qualitative analysis, the researcher analyzed students' comments based on the open-ended topics assigned to address in the journals. Patterns and trends were identified vis-à-vis our research questions and theoretical frameworks. The grounded theory method of data analysis (Corbin \& Strauss, 2008) was used. Themes were collapsed when they related to larger themes. Next, the three researchers met to discuss their individually created themes and to establish inter-rater reliability. Remarkably, we agreed on all but two sub-themes, with an inter-rater reliability of $88 \%$. Researchers noticed for the $88 \%$ of the themes agreed upon, synonyms were used, which possibly relates to our different fields. Researchers worked individually to reanalyze the two dissimilar themes and came to consensus.

\section{Findings}

Qualitative results provided answers for all the research questions. The student quotes, found in Table 1 to Table 7 , highlight phenomena and related themes resulting from responses to the research questions.

Researchers noticed a significant pattern that emerged across several participants relating to the observations, commentary and evaluations of bilingual/dual language strategies in the elementary classrooms. This salient theme across all responses was central to the experience of all bilingual teacher candidates along with related subthemes. Based on these results, it appears that participants found the cognitive (the head), affective (the heart), social (working with others), and multimodalities (connected to the psychomotor domain) to be important aspects of their learning experiences as defined through the aspects of learning defined by Dettmer (2006).

\subsection{Bilingual/Dual Language Strategies Phenomena}

In grounded theory methodology, phenomena were identified to represent what the data is mostly showing (Strauss \& Corbin, 1998). In this case, significantly, most participants highlighted new understandings based on bilingual and dual language strategies used in the elementary classrooms. Observations of bilingual/dual language classroom-level practices and instructional strategies permeated as a theme amongst the participants as evidenced in Table 1. Participants connected the theories underpinning effective bilingual and dual language practices to the observations in the classrooms. Consistent with theories of effective implementation of bilingual education, these practices rely heavily on the teacher supporting both languages through authentic interactions in positive learning environments that integrate a biliteracy approach to use language and literacy to communicate (Perez \& Torres-Guzman, 2002).

Table 1. Central Phenomena: Bilingual/Dual Language Strategies

\begin{tabular}{|l|l|}
\hline Participant \# & Quote \\
\hline \multirow{1}{*}{1} & $\begin{array}{l}\text { "They [students] used words like "maravilloso," } \\
\text { [marvelous] "genial" [great] etc. For a } \\
\text { second-grade class for me that was fantastic } \\
\text { because of my two semesters of observations in } \\
\text { the valley, I've never seen the students talk, write, } \\
\text { read, and listen for instructions in Spanish, usually } \\
\text { they just translate a word and continue the class in } \\
\text { English." }\end{array}$ \\
\hline \multirow{2}{*}{8} & $\begin{array}{l}\text { "The classroom was filled with students work, } \\
\text { entering the classroom to the right there was this } \\
\text { anchor chart of students duties in English and } \\
\text { Spanish (Dual language classroom) tables were } \\
\text { arranged in six per group (3 groups) total 15 } \\
\text { students." }\end{array}$ \\
\hline $\begin{array}{l}\text { "..I have only read about the different models of } \\
\text { bilingual education and seen some of the early exit } \\
\text { first had when I do my observations. The week I } \\
\text { took part in HISD has confirmed all I have read } \\
\text { about dual language. Children are learning } \\
\text { Spanish and English." }\end{array}$ \\
\hline
\end{tabular}

\subsection{Classroom Management and Related Themes}

Consistent with the research, classroom management surfaced as integral consideration in examining student learning in the classroom. Participants recognized the importance of establishing an organized productive classroom environment and managing student misbehavior effectively with classroom management as a theme with related subthemes as outlined in Table 2 and Table 3. Understanding the importance of maximizing learning time means setting up expectations, engaging in systematic routines and procedures and learning strategies.

As a related theme, learning strategies, delineated in Table 4, emerged as an important factor observed in the classroom. Participants discussed the role that effective use of learning strategies play in maintaining engagement of students in the classroom.

Table 2. Question, Subtheme 2: Classroom Management and Learning Environment

\begin{tabular}{|l|l|}
\hline Participant & Quote \\
\hline 4 & $\begin{array}{l}\text { "Today I went to a training with my host family. It } \\
\text { was called the "Tough Kids" training. This training } \\
\text { was created to help teachers' classroom management } \\
\text { skills. I didn't get to be with my kinder students, this } \\
\text { training gave me new knowledge that will be very } \\
\text { helpful during my first year of teaching." }\end{array}$ \\
\hline 6 & $\begin{array}{l}\text { "I noticed that the 2nd graders were always engaged, } \\
\text { but I believe this was because of the teacher's tactics. } \\
\text { She was constantly changing from activity to another. } \\
\text { She also took the students on frequent bathroom } \\
\text { breaks. This is something you don't see in 4th } \\
\text { grade...the 2nd grade teacher said it was a way to keep } \\
\text { them focused. Allowing them too much time on one } \\
\text { activity would cause them to lose interest." }\end{array}$ \\
\hline
\end{tabular}


Table 3. Question, Subtheme 4: Routines and Procedures

\begin{tabular}{|l|l|}
\hline Participant & Quote \\
\hline 8 & $\begin{array}{l}\text { "I had seen the teaching signal that my teacher used } \\
\text { so I used it when she left me in charge (5 } \\
\text { claps) ...using the teaching signal I was able to get } \\
\text { students attention..." }\end{array}$ \\
\hline 3 & $\begin{array}{l}\text { "I was also shown how her lesson plans are created, in } \\
\text { what time frame and how they are implemented in the } \\
\text { class." }\end{array}$ \\
\hline
\end{tabular}

Table 4. Learning Strategies

\begin{tabular}{|l|l|}
\hline Participant & Quote \\
\hline 1 & $\begin{array}{l}\text { "Taught a math lesson on equal than or greater than, } \\
\text { and less than. It was an awesome experience and all } \\
\text { students were engaged and loved the lesson. } \\
\text { Received good feedback from my mentor." }\end{array}$ \\
\hline \multirow{6}{*}{6} & $\begin{array}{l}\text { "Their schedule started off with what they called } \\
\text { "Reading Response". They would read for 30 } \\
\text { minutes, then take about 5-10 min writing up a } \\
\text { summary over what they had just read." }\end{array}$ \\
\hline
\end{tabular}

Table 5. Question, Subtheme 5: Feelings/Emotions

\begin{tabular}{|c|c|}
\hline Participant & Quote \\
\hline 4 & $\begin{array}{l}\text { "Arrived... feeling nervous but excited... and I was } \\
\text { able to relax and settle in... The nerves are definitely } \\
\text { sinking in for my first day with the students } \\
\text { tomorrow." }\end{array}$ \\
\hline 1 & $\begin{array}{l}\text { "My students couldn't stop hugging me, and crying, } \\
\text { begging me to stay." }\end{array}$ \\
\hline 7 & $\begin{array}{l}\text { "...I already feel attached to the kids. They're really } \\
\text { good kids. My favorite thing is...now I interact with } \\
\text { them in Spanish, mostly. Some students do feel more } \\
\text { comfortable in English so I would explain some } \\
\text { things in English for them." }\end{array}$ \\
\hline 5 & $\begin{array}{l}\text { "I learned all of the students name and they were all } \\
\text { excited about my visit for the week. My mentor } \\
\text { teacher has been amazing. She has taught me as much } \\
\text { as she could throughout the day. She even told me } \\
\text { that I seem like a person who can efficiently manage a } \\
\text { kinder classroom." }\end{array}$ \\
\hline 5 & $\begin{array}{l}\text { "I love today! When I arrived this morning the } \\
\text { students had a card for me. Each student made their } \\
\text { own cards for me and they are lovely. I swear I } \\
\text { wanted to cry as they were giving them. They all said } \\
\text { nice things like they will miss me or thanking me for } \\
\text { helping them read. I almost cried, this will be one of } \\
\text { the best part of the week." }\end{array}$ \\
\hline 2 & $\begin{array}{l}\text { "Friday was the day I was getting emotional and was } \\
\text { realizing that Houston ISD is/was a great District and } \\
\text { really want to stay and just finish my last semester...it } \\
\text { was a pleasure for me to experience this one-week } \\
\text { placement and learn from both the students and the } \\
\text { teacher." }\end{array}$ \\
\hline 3 & $\begin{array}{l}\text { "Maybe the observation hours have helped a lot to } \\
\text { feel prepared in front of a classroom but was not } \\
\text { nervous at all and mimicked what she did and even } \\
\text { incorporated a little of my ways of teaching as far as } \\
\text { explaining certain ideas." }\end{array}$ \\
\hline
\end{tabular}

\subsection{Feelings/Emotions and Bonding}

Another theme that surfaced were feelings, emotions and bonding elicited in the experiences of the participants as described in Table 5 and Table 6. For many involved in education there is a disproportionate emphasis on the knowledge that students attain from learning, the cognitive end-product (Op 't Eynde, P., and J. E. Turner. 2006).

Urban schools have greater needs to have teachers who express a caring attitude. The literature shows these children may experience a greater need to develop close relationships with teachers (Brown, 2004) who show warmth and affection to their students and see their relationship with students as a priority. Participants communicated this theme in feelings/emotions and bonding

Table 6. Question, Subtheme 7: Bonding

\begin{tabular}{|c|c|}
\hline Participant & Quote \\
\hline 2 & $\begin{array}{l}\text { "During the field trip I had the honor to have a } \\
\text { conversation with a parent of one of my students... } \\
\text { [student] talked about how I was his student teacher } \\
\text { and how much he liked having student teachers. His } \\
\text { Dad also wanted to know about the opportunity of } \\
\text { coming as a student teacher for a week and how we } \\
\text { were so fortunate to have all these great } \\
\text { opportunities." }\end{array}$ \\
\hline 5 & $\begin{array}{l}\text { "It was amazing having the students call me out for } \\
\text { help, raising their hands as the called out Ms----- } \\
\text { Also, I forgot to mention when I arrived the students } \\
\text { had some beautiful cards they had done for me; I will } \\
\text { save them forever." }\end{array}$ \\
\hline 7 & $\begin{array}{l}\text { "...I already feel attached to the kids. They're really } \\
\text { good kids. My favorite thing is...now I interact with } \\
\text { them in Spanish, mostly. Some students do feel more } \\
\text { comfortable in English so I would explain some } \\
\text { things in English for them." }\end{array}$ \\
\hline
\end{tabular}

\subsection{Diversity}

Another theme that emerged was that of participants providing commentary on the diversity of the school district as represented in quotes in Table 7. The ethnic, racial, cultural, social, and linguistic diversity that is growing by leaps and bounds in U.S. schools and society is a defining feature of our lives, even though we often try to deny its existence or minimize its significance in the educational enterprise (Gay, 2010). In this large urban district, the positive impact of having exposure to greater level of diversity was a theme that resonated with many of the participants. Teacher candidates gain a global perspective of diversity reinforcing teacher dispositions of respect and value differences along with skills for working in these diverse settings (Akiba, Cockrell, Simmons, Han, \& Agarwal, 2010). 
Table 7. Question, Subtheme 6: Diversity

\begin{tabular}{|l|l|}
\hline Participant & Quote \\
\hline \multirow{5}{*}{ "The first thing I noticed at the assembly was the } \\
diversity among students. The school was made up \\
of a majority of African American and Hispanic \\
students with a small percentage of other races like \\
whites and Asian Americans. This is clearly \\
something new to me because of my experiences in \\
the valley, the majority of the classrooms are made \\
up of Hispanic students."
\end{tabular}

\section{Conclusions}

As bilingual teacher candidates develop their teaching skills and build a repertoire of strategies to use in bilingual/dual language classrooms, practice in applying these in different classroom contexts is highly valued. By offering a group of bilingual teacher candidates opportunities to assume a week-long clinical experience in one of the biggest urban school districts in the state, they were exposed to vast student diversity, new teaching and classroom management practices, and occasion to reinforce their interest in choosing the teaching profession. This experience was in addition to their field-based assignments as part of their educator preparation program, separate and prior to their student/clinical teaching.

Our study is important because a dearth of research exists about learning experiences in higher education for Latinos, specifically pre-service teachers. Furthermore, because teacher-retention rates for Latinos are lower than for whites (U.S. Department of Education, 2016), more field-based experiences and exposure to different educational settings in varied communities might make Latinos teaching more rewarding; participants in the present study were excited, challenged, and discovered that they loved working in dual language classrooms. The levels of increased self-confidence were evident in the journals they shared.

The "clinically rich" experiences described by our students sets the stage for them to consider working in a large urban setting. The urban district administrators awarded letters of commitment to hire these potential teachers when they graduate and are certified. The experience in the urban district was positive and as a recruitment effort extremely effective. These preservice teachers are already making plans to work for this large urban district. Each time we have offered this opportunity the number of our pre-service teachers increases. Additional districts are now modeling their recruitment practices after this because of the success of bringing in qualified new teachers to the dual-language program.

Under current Texas Administrative Code (TAC) and CAEP accreditation standards, there is a call for pre-service candidates to experience diverse educational settings. Having pre-service candidates attend and participate in bilingual dual language classrooms in an urban setting seems to allow us to address these standards. Consideration of the latter and the possibility of scaling to a greater number of pre-service teacher candidates become challenging and problematic. There may be a need to examine how technology may assist with continued efforts and scaling.

These researchers recognize there are opportunities to enrich the placement experience for pre-service teacher candidates by purposefully arranging and planning in-class experiences utilizing framed questions, organized, collaborated lessons with the district, and further conducting debriefing sessions with them to provide further learning support.

As the themes and sub-themes emerge, there may be further opportunity for our work and others to envision the connectedness of the field experience. In other words, how are these themes and sub-themes closely related, so we plan the experience and instructional supports in ways that go deeper in depth and draw out pre-service teacher candidates' beliefs and values as they relate to their future work with PK-12 students.

\section{REFERENCES}

[1] Corbin, J. \& Strauss, A. (2008). Basics of qualitative research: Techniques and procedures for developing grounded theory (2nd ed.). Thousand Oaks, CA: Sage Publications, Inc.

[2] Damasio, A. 2003. Looking for Spinoza: Joy, Sorrow and the Feeling Brain. London: Vintage).

[3] Dettmer, P. (2006). New blooms in established fields: Four domains of learning and doing. Roeper Review, 28 (2), $70-82$.

[4] Immordino-Yang, M. H. (2016). "Introduction: Why Emotions are Integral to Learning." In Emotions, Learning, and the Brain: Exploring the Educational Implications of Affective Neuroscience, edited by M. H. Immordino-Yang, 17-24. New York: Norton.).

[5] Kozulin, A. (Ed. and Trans.) (1986). Lev Vygotsky: Thought and language. Cambridge, MA: The MIT Press.

[6] Leech, N. \& Onwuegbuzie, A. (2011). Beyond constant comparison qualitative data analysis: Using NVivo. School 
Psychology Quarterly, 26(1), 70-84. doi: 10.1037/a002271

1

[7] Leedy, P. D. \& Ormrod, J. E. (2016). Practical research: Planning and design. Boston, MA: Pearson.

[8] Joyce, B., Weil, M. and Calhoun, E. (2015). Models of Teaching, Ninth Ed., Pearson Education, Inc., Boston, MA.

[9] National Council for Accreditation of Teacher Education. (2010). Transforming teacher education through clinical practice: A national strategy to prepare effective teachers. Washington, D. C.: Author.

[10] New York State Department of Education. (2011). Graduate level clinically rich teacher preparation pilot program: 2011-2016. Retrieved from http://www.p12.nysed.gov/co mpcontracts/rttt/teacherprep/

[11] Op't Eynde, P., and J. E. Turner, (2006). "Focusing on the Complexity of Emotion-Motivation Issues in Academic Learning: A Dynamical Component Systems Approach." Educational Psychology Review 18: 361-376. doi: 10.1007/s10648-006-9031-2).

[12] Piaget, J. (2001). ). The psychology of intelligence: Routledge Classics (2nded.). Abingdon, OH: Routledge.

[13] Sawyer, J. \& Obeid, R. (2017). Cooperative and collaborative learning: Getting the best of both words. In R. Obeid, A. Schwartz, C. Shane-Simpson \& P. J. Brooks (Eds.) How We Teach Now: The GSTA Guide to Student-Centered Teaching. Society for the Teaching of Psychology e-book. Retrieved from http://teachpsych.org/e books

[14] U.S. Census Bureau. (2010). Quick facts. Washington, D. C.: Author.

[15] Vygotsky, L. S. (1978). Mind in society: The development of higher mental process. Cambridge, Mass.: Harvard University Press. 